\title{
Diversity of Ephemeroptera (Insecta) of the Serra da Mantiqueira and Serra do Mar, southeastern Brazil
}

\author{
Ana Emilia Siegloch ${ }^{1,2}$, Claudio Gilberto Froehlich ${ }^{1} \&$ Marcia Regina Spies $^{3}$
}

${ }^{1}$ Faculdade de Filosofia, Ciências e Letras de Ribeirão Preto, Universidade de São Paulo, Departamento de Ciências Biológicas, Programa de Pós-Graduação em Entomologia, Av. Bandeirantes, 3900, Bairro Monte Alegre 14040-901, Ribeirão Preto, -SP, Brasil. cgfroeh@ffclrp.usp.br ${ }^{2}$ Endereço atual: Universidade Federal de Santa Catarina, Centro de Ciências Biológicas, Departamento de Ecologia e Zoologia, Programa de Pós Graduação em Ecologia, Campos Universitário, s/n, Bairro Córrego Grande, 88040-900, Florianópolis - SC, Brasil. asiegloch@gmail.com ${ }^{3}$ Universidade Federal do Pampa, Campus São Gabriel, Av. Antônio Trilha, 1847, 97300-000, São Gabriel-RS, Brasil. marciaspies@gmail.com

\begin{abstract}
Diversity of Ephemeroptera (Insecta) of the Serra da Mantiqueira and Serra do Mar, southeastern Brazil. The aim of this study was to inventory the mayfly fauna, based on nymphal and alate stages, in Serra da Mantiqueira and in Serra do Mar, São Paulo State, as well as to present information about habitats used by the genera. Nymphs were collected in several streams and mesohabitats with a Surber sampler and the winged stages with light attraction methods, entomological nets, and Malaise traps. In all, eight families and 33 genera were recorded, representing a very significant portion of the Brazilian fauna ( $80 \%$ of families and $49 \%$ of genera). Furthermore, it was possible to identify 11 species, of which two are new records for the state: Tricorythodes santarita Traver and Caenis reissi Malzacher. Despite the high diversity recorded, the accumulation curves presented an ascending form, indicating an increase in the number of genera with additional sampling effort. The high richness found in these areas are in agreement with the high biodiversity of the Atlantic Forest biome and the sampling effort employed, which included the use of different methods, the collection of both nymphs and winged stages, and the sampling of a large area with diverse streams and habitats.
\end{abstract}

KEYWORDS. Aquatic Insect; Faunal Survey; Lotic Environment; Neotropical Region.

RESUMO. Diversidade de Ephemeroptera (Insecta) da Serra da Mantiqueira e Serra do Mar, região Sudeste do Brasil. O objetivo do trabalho foi inventariar a fauna de Ephemeroptera, com base em ninfas e estágios alados, da Serra da Mantiqueira e Serra do Mar no estado de São Paulo, bem como gerar informações sobre os hábitats utilizados pelos gêneros registrados. As ninfas foram colecionadas em diversos riachos e mesohábitats com amostrador de Surber e os alados por métodos de atração luminosa, rede entomológica e armadilha de Malaise. Considerando o esforço conjunto de todos os métodos de coleta foram registradas oito famílias e 33 gêneros, o que representa uma porção bastante significativa da fauna brasileira ( $80 \%$ das famílias e $49 \%$ dos gêneros). Além disso, foi possível identificar 11 espécies, das quais Tricorythodes santarita Traver e Caenis reissi Malzacher são novos registros para o estado. Apesar da alta diversidade registrada, as curva de acumulação de gêneros não atingiram a assíntota, indicando um aumento no número de gêneros com o incremento do esforço amostral. A alta riqueza encontrada nesse estudo está de acordo com a grande biodiversidade do bioma Mata Atlântica e ao esforço amostral empregado, que abrangeu o uso de diferentes métodos de coleta, coleta de ninfas e estágios alados e amostragem de uma grande área com diversos riachos e habitats.

PALAVRAS-CHAVES. Ambiente Lótico; Inventário Faunístico; Insetos Aquáticos; Região Neotropical.

The Order Ephemeroptera is relatively small, with about 3,000 species, 42 families and 400 genera known in the world (Barber-James et al.2008). For South America, approximately 460 species have been reported, Brazil and Argentina showing the highest number of species (Domínguez \& Fernandez 2009; Domínguez et al. 2011). In Brazil, the increase in the number of studies on mayflies in recent years has contributed to a better knowledge of the biodiversity of the order in almost all regions. There are about of 258 species reported for the country with the highest number of species reported in the Southeastern Region (Domínguez et al. 2011; Salles et al. 2011; Gonçalves et al. 2011, 2012). In the State of São Paulo 53 species were recorded (Mariano \& Polegatto 2011).

Mayfly immatures are important components of aquatic assemblages in freshwater environments due to their high abundance and richness and their role in the trophic chain (Domínguez et al. 2006). Nymphs are considered mainly collectors and filter-feeders of organic matter or scrapers of periphyton, while shredders and predators are rare (Cummins \& Klug 1979; Brittain 1982; Baptista et al. 2006). Some species are even able of changing the functional feeding group, with great flexibility in the use of food resources (Domínguez et al. 2006). Nymphs, therefore, have an important role in nutrient cycling, since they process large amounts of organic matter from the riparian vegetation and periphyton in the aquatic environment (Moulton et al. 2004, Domínguez et al. 2006).

Mayfly nymphs occur in a wide variety of habitats, but are highly diverse in lotic systems with rocky substrate and fast flowing waters. This group, together with the Trichoptera and Plecoptera, are excellent biological indicators of water quality, due their sensitivity to pollution and to habitat fragmentation (Rosenberg \& Resh 1993). These orders are intensively used in biological monitoring in water quality 
programs of rivers and streams and in environmental impact evaluations (Compin \& Céréghino 2003).

Knowledge about the diversity of mayflies is still fragmentary in Brazil, as shown in the last checklist, where five states do not have any records of Ephemeroptera and nine states have less than 10 species (Salles et al. 2011). In São Paulo, the number of studies on ecology, taxonomy, and biology of Ephemeroptera assemblages are increasing in recent years (e.g., Crisci-Bispo et al. 2007; Polegatto \& Froehlich 2003; Mariano $\&$ Polegatto 2011) and led to the current knowledge of biodiversity in the state. On the other hand, due to the increasing human occupation and exploitation of natural areas, faunal inventories especially those that include both immature and alates are relevant to the establishment of priority areas for biodiversity conservation. Thus, mayflies diversity and ecological requirements could be used as tools to evaluate environmental impacts on water resources and drive future research on applied ecology. The present study had the purpose to inventory the mayfly in mountainous regions in the state of São Paulo, as well as to provide information about habitat preference and activity of the recorded genera.

\section{MATERIAL AND METHODS}

Study area. The study was conducted in two major mountain chains of São Paulo State: Serra da Mantiqueira and Serra do Mar (Fig. 1).

In Serra da Mantiqueira, the samplings were concentrated in the Parque Estadual de Campos do Jordão (PECJ) (22 $30^{\circ}$ to $22^{\circ} 41^{\prime} \mathrm{S}, 45^{\circ} 27^{\prime}$ to $\left.45^{\circ} 31^{\prime} \mathrm{W}\right)$ and in the municipality of Pindamonhangaba (Reserva Particular São Sebastião do Ribeirão Grande and Parque Municipal de Trabijú) (22 $44^{\circ}$ to $22^{\circ} 50^{\prime} \mathrm{S}$ to $45^{\circ} 27^{\prime}$ to $\left.45^{\circ} 31^{\prime} \mathrm{W}\right)$. In Serra do Mar, the collections were made in Parque Estadual da Serra do Mar, nuclei Santa Virginia $\left(23^{\circ} 17^{\prime}\right.$ to $23^{\circ} 24^{\prime} \mathrm{S}, 4^{\circ} 03^{\prime}$ to $45^{\circ} 11^{\prime} \mathrm{W}$ ) and Picinguaba $\left(23^{\circ} 15^{\prime}\right.$ to $23^{\circ} 27^{\prime} \mathrm{S}, 45^{\circ} 03^{\prime}$ to $\left.45^{\circ} 15^{\prime} \mathrm{W}\right)$.

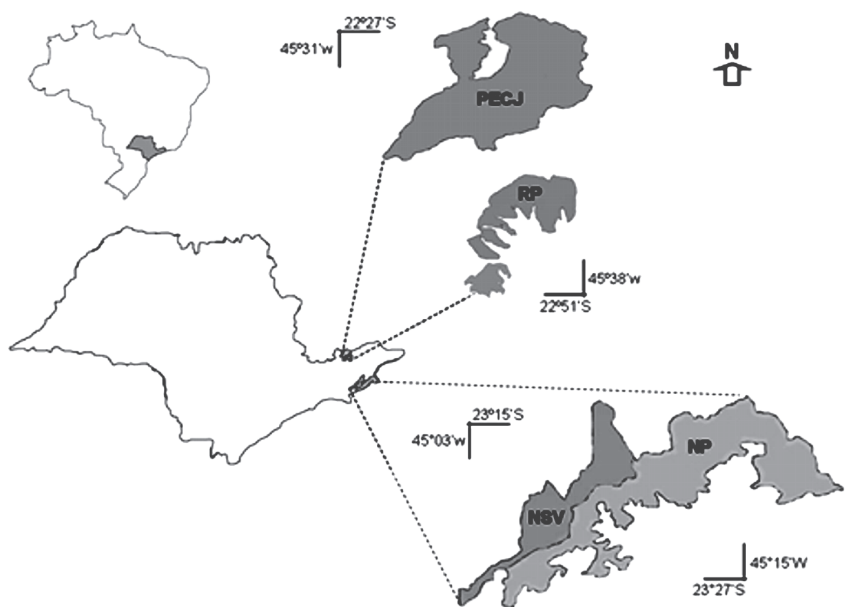

Fig. 1. Geographical localization of the Serra da Mantiqueira (PECJ - Parque Estadual de Campos do Jordão, RP - Pindamonhangaba region) and Serra do Mar (Parque Estadual da Serra do Mar, NSV - Santa Virgínia nucleus, NP - Picinguaba nucleus) in São Paulo State (Segura et al. 2012).
The PECJ has an area of 8,385 ha in the municipality of Campos do Jordão and has an average altitude of 1,650 m. The vegetation consists of Upper-Montane Tropical Rain Forest, Mixed Forest (predominance of Araucaria angustifolia) and Grassland Fields. The climate of this region, according to the classification of Köppen, is Cfb, subtropical of altitude, without dry season, average temperature of warmest month below $22^{\circ} \mathrm{C}$ and annual average rainfall of 1,800 $\mathrm{mm}$ (Seibert 1975). In the region of Pindamonhangaba, the vegetation consists of Grassland Fields and Montane Tropical Rain Forest (Hueck 1972). However, the original vegetation is currently found only on the slopes of mountains. The climate is Cwa, humid subtropical with hot summers and dry winters and annual average rainfall of $1,000 \mathrm{~mm}$.

The Santa Virginia nucleus is located in a narrow strip between the Atlantic plateau and the Paraíba do Sul River valley. The altitude ranges from 870 to $1,100 \mathrm{~m}$ and the vegetation is characterized by Montane Tropical Rain Forest, with some small patches of Altitude Fields and Cloud Forest. The climate is classified as Af, humid tropical, with an annual average rainfall of 2,180 $\mathrm{mm}$, the wettest months being December, January and February. The Picinguaba nucleus is located in the municipality of Ubatuba and connects the Parque Estadual da Serra do Mar to the Parque Nacional da Bocaina, forming a large protected area. The nucleus covers an altitudinal gradient from level zero to $1,300 \mathrm{~m}$, protecting a gradient of vegetation and ecosystems from coastal dunes and mangrove to Montane Tropical Rain Forest. The climate of the area is Af, according to Köppen, but with high precipitation during all months of the year due to the orographic effect.

Sampling design. Mayfly immatures were collected between May 2005 and November 2008 in four areas, exploring different environments (e.g., streams of low and middle order and lakes) and stream habitats (waterfall, riffle and pool areas with deposits of leaves, roots, sand, and stone). In all, around 80 stream e 420 samples of stream substrate were collected with a Surber sampler (area of $0.0361 \mathrm{~m}^{2}$ and mesh of $0.25 \mathrm{~mm}$ ). Three hundred and nine samples were collected from approximately 50 streams in the Serra da Mantiqueira and 114 samples were collected from 30 streams in the Serra do Mar. After collection, the material was fixed in 4\% formaldehyde and transported to the laboratory, washed in a mesh of $0.25 \mathrm{~mm}$, then sorted under a stereomicroscope and preserved in $80 \%$ ethanol.

During the same period, mayfly alates (adults and subimagos) were collected to complement the survey using white sheet light traps and trays with $80 \%$ ethanol and ultraviolet and fluorescent lamps over them near the banks of streams; a total of 132 samples were collected, 65 samples in the Serra da Mantiqueira and 67 samples in the Serra do Mar. The traps remained in place from twilight for about two hours. Moreover, the vegetation of the stream bank was swept with an entomological net to collect alates and in Parque Estadual de Campos do Jordão a Malaise trap was installed on a stream for a period of two consecutive years (2005-2007) and the material retained in the ethanol jar was collected every month. 
Mayflies were fixed and preserved in $80 \%$ ethanol, but, when manually collected, live subimagos were put in small jars until emergence of the adults. Nymphs and alates were identified to genus level and, when possible, adults to species using published books (Domínguez et al. 2006; Domínguez \& Fernandez 2009), taxonomic articles (e.g. Salles et al. 2004; Dias et al. 2006), and help from experts.

Data analysis. The total genus richness and sampling effort in Serra da Mantiqueira and Serra do Mar were evaluated by randomized accumulation curves and by qualitative nonparametric richness estimators (Bootstrap, ICE and Jackknife 1 and 2). The use of randomized curves was adopted to avoid variation in curve shape during the addition of samples (Colwell \& Coddington 1994). The Jackknife and ICE estimate the richness based on rare species frequency. They differ only in the criterion by which a species is considered rare. For example, in Jackknife 1, rare species are those that occur in only one sample, while in Jackknife 2 rare species are those that occur in only one and two sample units (Santos 2003). For the ICE estimator, the user chooses the frequency to define rare species, but common choices are the interval one to ten sample units (Santos 2003). In this study, rare genera were defined as those that occurred in up to 10 sample units in the data set. Bootstrap uses frequency data of all taxa sampled and not only those of rare species (Santos 2003). The curves were generated from 500 randomizations in EstimateS 8 software (Colwell 2006). The accumulation curves and estimates were obtained separately for nymphs and alates collected by Surber sampler and light traps, respectively.

The rarefaction method was used to compare nymphal richness between Serra da Mantiqueira and Serra do Mar and between the habitats sampled (stones in riffles, leaf packs in riffles, leaf packs in pools, sand in pool and waterfall). For rarefaction was used the highest comparable abundance: 3,379 individuals between mountains; 535 individuals between habitats of Serra do Mar; and 411 individuals between habitats of Serra da Mantiqueira. The method was used to remove sampling effects on taxonomic richness (Gotelli \& Colwell 2001). Curves were generated from 1,000 randomizations with a confidence interval of $95 \%$ and performed using EcoSim 7.0 program (Gotelli \& Entsminger 2004).

\section{RESULTS}

Eight families and 33 genera of Ephemeroptera were found, based on the combined effort from all sampling methods used in different environments and both life stages, in addition, it was possible to identify 11 species (Table I). Among the families, Baetidae and Leptophlebiidae were the most representative, with 12 and 10 genera, respectively.

In streams of Serra da Mantiqueira, eight families and 27 genera were found, of which two genera were restricted to this region: Callibaetis and Lachlania (Table I). In PECJ six families and 26 genera were recorded, of which 17 genera were collected exclusively in the nymphal stage and nine in both, nymphs and alates. In the Pindamonhangaba region, six families and 24 genera were found, of these 14 genera were collected exclusively as nymphs, one as alate and nine genera in both stages.

In streams of Serra do Mar, seven families and 31 genera were recorded, of which Aturbina, Cryptonympha, Waltzoyphius, Perissophlebiodes, Ulmeritoides and Asthenopus occurred only in this region (Table I). In Santa Virginia, seven families and 29 genera were found, 19 genera as nymphs and 10 as nymphs and alates. In Picinguaba, five families and 21 genera were recorded, of which 10 genera were collected as nymphs and 11 in both stages.

Among the collecting methods of alates, light traps (sheet or tray with ethanol) showed the highest richness, with 16 genera collected. Caenis, Campylocia, and Campsurus were collected only at the white sheet and Hermanella and Tricorythopsis were captured exclusively by the plastic trays. Hagenulopsis diptera Ulmer was collected only with entomological nets and Malaise traps.

The accumulation curves of genera evidenced a greater richness of nymphs and alates for Serra do Mar and Serra da Mantiqueira with increasing sampling effort, since there is a wide variation around the mean curve (Fig. 2). Statistical richness estimators suggest a larger number of genera in Serra do Mar (Fig. 2).

Rarefaction curves based on immatures showed higher genera richness in Serra do Mar for a comparable abundance of 3,379 individuals (Fig. 3A). In Serra do Mar, the richness in stones in riffles was similar to that of leaf packs in pools, but higher than the others mesohabitats for a comparable abundance of 535 individuals (Fig. 3B). Richness of mesohabitats stones in riffles, leaf packs in riffles and pools, and sand was similar in the Serra da Mantiqueira for a comparable abundance of 411 individuals (Fig. 3C). Sporadic samples were also collected in dam and sand mesohabitats in the Serra do Mar and lentic environment and macrophytes in the Serra da Mantiqueira, but such samples were not included in the rarefaction analysis due their low numbers.

\section{DISCUSSION}

Currently, there are 10 families, 68 genera and 258 species of Ephemeroptera recorded in Brazil (Domínguez et al. 2011; Salles et al. 2011; Gonçalves et al. 2011, 2012). In São Paulo State, there are records of nine families, 37 genera and 53 species (Mariano \& Polegatto 2011). Thus, the present study, which covers the most important mountainous regions of São Paulo State, recorded a significant portion of the fauna composition of Brazil ( $80 \%$ of families and $49 \%$ of genera) and of the state ( $89 \%$ of families and genera). In addition, the species Tricorythodes santarita and Caenis reissi are new records for São Paulo State.

The high richness of Ephemeroptera found in this study is highlighted by comparison with other studies of different environments and regions of Brazil, based only on sampling nymphs (e.g., Crisci-Bispo et al. 2007; Bispo \& Oliveira 2007; Siegloch et al. 2008; Righi-Cavallaro et al. 2010). These re- 
Table I. Taxonomic composition of Ephemeroptera based on nymphs (by mesohabitat) and alates (by sampling method) in Serra da Mantiqueira and Serra do Mar between May 2005 and November 2008. StR = stones in riffles $(\mathrm{n}=152) ; \mathrm{LR}=$ leaf packs in riffles $(\mathrm{n}=116) ; \mathrm{LP}=$ leaf packs in pools $(\mathrm{n}=86)$; $\mathrm{SaP}=$ sand in pool $(\mathrm{n}=45) ; \mathrm{W}=$ waterfall $(\mathrm{n}=24) ; \mathrm{L}=$ lentic $(\mathrm{n}=4) ; \mathrm{D}=$ dam $(\mathrm{n}=2) ; \mathrm{T}=$ tray light attraction $(\mathrm{n}=66) ; \mathrm{S}=$ white sheet light attraction $(\mathrm{n}=55) ; \mathrm{EN}=$ entomological net $(\mathrm{n}=11) ; \mathrm{M}=$ Malaise trap $(\mathrm{n}=2$ years $)$.

\begin{tabular}{|c|c|c|c|c|c|c|c|c|c|c|c|c|c|c|c|c|c|c|c|}
\hline \multirow{3}{*}{ Taxa } & \multicolumn{10}{|c|}{ Serra da Mantiqueira } & \multicolumn{9}{|c|}{ Serra do Mar } \\
\hline & \multicolumn{6}{|c|}{ Nymphs } & \multicolumn{4}{|c|}{ Alates } & \multicolumn{6}{|c|}{ Nymphs } & \multicolumn{3}{|c|}{ Alates } \\
\hline & StR & LR & LP & $\mathrm{SaP}$ & W & Le & $\mathrm{T}$ & $\mathrm{S}$ & EN & M & StR & LR & LP & $\mathrm{SaP}$ & W & $\mathrm{D}$ & $\mathrm{T}$ & $\mathrm{S}$ & EN \\
\hline \multicolumn{20}{|l|}{ Baetidae } \\
\hline Americabaetis Kluge, 1992 & $\mathrm{x}$ & $\mathrm{X}$ & $\mathrm{x}$ & $\mathrm{x}$ & $\mathrm{x}$ & & & & & & $\mathrm{x}$ & $\mathrm{x}$ & $\mathrm{x}$ & & $\mathrm{x}$ & $\mathrm{x}$ & & & \\
\hline Apobaetis Day, 1955 & $\mathrm{x}$ & & $\mathrm{x}$ & $\mathrm{x}$ & & & & & & & & & $\mathrm{x}$ & & & & & & \\
\hline Aturbina Lugo-Ortiz \& McCafferty, 1996 & & & & & & & & & & & & & & & & $\mathrm{x}$ & & & \\
\hline Baetodes Needham \& Murphy, 1924 & $\mathrm{x}$ & $\mathrm{x}$ & $\mathrm{x}$ & $\mathrm{x}$ & $\mathrm{x}$ & & & & & & $\mathrm{x}$ & $\mathrm{x}$ & $\mathrm{x}$ & & $\mathrm{x}$ & & & & \\
\hline Callibaetis Eaton, 1881 & & & & & & $\mathrm{x}$ & & & & & & & & & & & & & \\
\hline Camelobaetidius Demoulin, 1966 & $\mathrm{x}$ & & & & & & & & & & $\mathrm{x}$ & & $\mathrm{x}$ & & $\mathrm{x}$ & & & & \\
\hline Cloeodes Traver, 1938 & $\mathrm{x}$ & $\mathrm{x}$ & $\mathrm{x}$ & $\mathrm{x}$ & & & & & & & $\mathrm{x}$ & $\mathrm{x}$ & $\mathrm{x}$ & & & & & & \\
\hline Cryptonympha Lugo-Ortiz \& McCafferty, 1998 & & & & & & & & & & & & $\mathrm{x}$ & & & & & & & \\
\hline Paracloeodes Day, 1955 & $\mathrm{x}$ & $\mathrm{x}$ & $\mathrm{x}$ & $\mathrm{x}$ & & & & & & & $\mathrm{x}$ & $\mathrm{x}$ & $\mathrm{x}$ & & & $\mathrm{x}$ & & & \\
\hline Tupiara Salles et al., 2003 & $\mathrm{x}$ & $\mathrm{x}$ & $\mathrm{x}$ & $\mathrm{x}$ & $\mathrm{x}$ & & & & & & $\mathrm{x}$ & $\mathrm{x}$ & & & & & & & \\
\hline Waltzoyphius McCafferty \& Lugo-Ortiz, 1995 & & & & & & & & & & & & & $\mathrm{x}$ & & & $\mathrm{x}$ & & & \\
\hline Zelusia Lugo-Ortiz \& McCafferty, 1998 & $\mathrm{x}$ & $\mathrm{x}$ & $\mathrm{x}$ & $\mathrm{x}$ & & & & & & & $\mathrm{x}$ & $\mathrm{x}$ & $\mathrm{x}$ & & & $\mathrm{x}$ & & & \\
\hline \multicolumn{20}{|l|}{ Caenidae } \\
\hline Caenis Stephens, 1835 & $\mathrm{x}$ & & & & & & & & & & & & $\mathrm{x}$ & & & & $\mathrm{x}$ & & \\
\hline Caenis reissi Malzacher, 1986 & & & & & & & & & & & & & & & & & & $\mathrm{x}$ & \\
\hline \multicolumn{20}{|l|}{ Euthyplociidae } \\
\hline Campylocia Needham \& Murphy, 1924 & $\mathrm{x}$ & $\mathrm{x}$ & $\mathrm{x}$ & $\mathrm{x}$ & & & $\mathrm{x}$ & & & & $\mathrm{x}$ & $\mathrm{x}$ & $\mathrm{x}$ & & & & $\mathrm{x}$ & & \\
\hline \multicolumn{20}{|l|}{ Leptohyphidae } \\
\hline Leptohyphodes Ulmer, 1920 & $\mathrm{x}$ & $\mathrm{x}$ & $\mathrm{x}$ & $\mathrm{x}$ & & & $\mathrm{x}$ & $\mathrm{x}$ & & & $\mathrm{x}$ & $\mathrm{x}$ & $\mathrm{x}$ & & & $\mathrm{x}$ & & & \\
\hline Leptohyphodes inanis Pictet, 1843 & & & $\mathrm{x}$ & & & & $\mathrm{x}$ & $\mathrm{x}$ & & & & & & & & & & & $\mathrm{x}$ \\
\hline Leptohyphes Eaton, 1882 & $\mathrm{x}$ & $\mathrm{x}$ & $\mathrm{x}$ & $\mathrm{x}$ & & & $\mathrm{x}$ & $\mathrm{x}$ & & & & $\mathrm{x}$ & & & & & $\mathrm{x}$ & & \\
\hline Traverhyphes Molineri, 2001 & $\mathrm{x}$ & $\mathrm{x}$ & $\mathrm{x}$ & $\mathrm{x}$ & $\mathrm{x}$ & & $\mathrm{x}$ & $\mathrm{x}$ & & & $\mathrm{x}$ & $\mathrm{x}$ & $\mathrm{x}$ & & $\mathrm{x}$ & & $\mathrm{x}$ & $\mathrm{x}$ & \\
\hline Traverhyphes yuati Molineri, 2001 & & & & & & & $\mathrm{x}$ & & & & & & & & & & $\mathrm{x}$ & & \\
\hline Traverhyphes edmundsi Allen, 1973 & & & & & & & & & & & & & & & & & $\mathrm{x}$ & & \\
\hline Tricorythodes Ulmer, 1920 & $\mathrm{x}$ & $\mathrm{x}$ & $\mathrm{x}$ & $\mathrm{x}$ & $\mathrm{x}$ & & $\mathrm{x}$ & $\mathrm{x}$ & $\mathrm{x}$ & & $\mathrm{x}$ & $\mathrm{x}$ & & & & & $\mathrm{x}$ & $\mathrm{x}$ & \\
\hline Tricorythodes santarita Traver, 1959 & & & & & & & $\mathrm{x}$ & $\mathrm{x}$ & & & & & & & & & & & \\
\hline Tricorythopsis Traver, 1958 & $\mathrm{x}$ & $\mathrm{x}$ & $\mathrm{x}$ & & $\mathrm{x}$ & & & $\mathrm{x}$ & & & $\mathrm{x}$ & $\mathrm{x}$ & $\mathrm{x}$ & & $\mathrm{x}$ & $\mathrm{x}$ & & & \\
\hline \multicolumn{20}{|l|}{ Leptophlebiidae } \\
\hline Askola Peters, 1969 & $\mathrm{x}$ & $\mathrm{x}$ & $\mathrm{x}$ & $\mathrm{x}$ & & & $\mathrm{x}$ & $\mathrm{x}$ & $\mathrm{x}$ & $\mathrm{x}$ & $\mathrm{x}$ & $\mathrm{x}$ & $\mathrm{x}$ & & & & $\mathrm{x}$ & $\mathrm{x}$ & \\
\hline Askola froehlichi Peters, 1969 & & & & & & & $\mathrm{x}$ & & & & & & & & & & $\mathrm{x}$ & & \\
\hline Farrodes Peters, 1971 & $\mathrm{x}$ & $\mathrm{x}$ & $\mathrm{x}$ & $\mathrm{x}$ & & & $\mathrm{x}$ & $\mathrm{x}$ & & & $\mathrm{x}$ & $\mathrm{x}$ & $\mathrm{x}$ & & & & $\mathrm{x}$ & $\mathrm{x}$ & \\
\hline Farrodes carioca Domínguez et al., 1996 & & & & & & & $\mathrm{x}$ & & & & & & & & & & $\mathrm{x}$ & $\mathrm{x}$ & \\
\hline Hagenulopsis Ulmer, 1920 & $\mathrm{x}$ & $\mathrm{x}$ & $\mathrm{x}$ & $\mathrm{x}$ & & & $\mathrm{x}$ & & $\mathrm{x}$ & $\mathrm{x}$ & $\mathrm{x}$ & $\mathrm{x}$ & $\mathrm{x}$ & & & & $\mathrm{x}$ & & $\mathrm{x}$ \\
\hline Hagenulopsis diptera Ulmer, 1920 & & & & & & & & & $\mathrm{x}$ & $\mathrm{x}$ & & & & & & & & & $\mathrm{x}$ \\
\hline Hermanella Needham \& Murphy, 1924 & $\mathrm{x}$ & $\mathrm{x}$ & $\mathrm{x}$ & & $\mathrm{x}$ & & & $\mathrm{x}$ & & & & & & & & & & & \\
\hline Hylister Domínguez \& Flowers, 1989 & $\mathrm{x}$ & $\mathrm{x}$ & $\mathrm{x}$ & & & & & & & & $\mathrm{x}$ & $\mathrm{x}$ & & & $\mathrm{x}$ & & & & \\
\hline Massartella Lestage, 1930 & $\mathrm{x}$ & $\mathrm{x}$ & $\mathrm{x}$ & $\mathrm{x}$ & & & $\mathrm{x}$ & $\mathrm{x}$ & $\mathrm{x}$ & $\mathrm{x}$ & $\mathrm{x}$ & $\mathrm{x}$ & $\mathrm{x}$ & & & $\mathrm{x}$ & $\mathrm{x}$ & $\mathrm{x}$ & \\
\hline Massartella brieni Lestage, 1924 & & & & & & & $\mathrm{x}$ & & & & $\mathrm{x}$ & & & & & & & & \\
\hline Miroculis Edmunds, 1963 & $\mathrm{x}$ & $\mathrm{x}$ & $\mathrm{x}$ & & & & $\mathrm{x}$ & $\mathrm{x}$ & & & $\mathrm{x}$ & $\mathrm{x}$ & $\mathrm{x}$ & $\mathrm{x}$ & & $\mathrm{x}$ & $\mathrm{x}$ & $\mathrm{x}$ & $\mathrm{x}$ \\
\hline Miroculis mourei Savage \& Peters, 1983 & & & & & & & $\mathrm{x}$ & & & & & & & & & $\mathrm{x}$ & & & \\
\hline Perissophlebiodes Savage, 1983 & & & & & & & & & & & $\mathrm{x}$ & & & & & & & & \\
\hline Thraulodes Ulmer, 1920 & $\mathrm{x}$ & $\mathrm{x}$ & $\mathrm{x}$ & $\mathrm{x}$ & & & $\mathrm{x}$ & $\mathrm{x}$ & & & $\mathrm{x}$ & $\mathrm{x}$ & $\mathrm{x}$ & & & & $\mathrm{x}$ & $\mathrm{x}$ & $\mathrm{x}$ \\
\hline Ulmeritoides Traver, 1959 & & & & & & & & & & & $\mathrm{x}$ & & $\mathrm{x}$ & & & & $\mathrm{x}$ & $\mathrm{x}$ & \\
\hline Melanemerellidae & & & & & & & & & & & & & & & & & & & \\
\hline Melanemerella Ulmer, 1920 & $\mathrm{x}$ & $\mathrm{x}$ & $\mathrm{x}$ & $\mathrm{x}$ & & & & & & & $\mathrm{x}$ & $\mathrm{x}$ & $\mathrm{x}$ & & & $\mathrm{x}$ & & & \\
\hline Melanemerella brasiliana Ulmer, 1920 & $\mathrm{x}$ & $\mathrm{x}$ & $\mathrm{x}$ & $\mathrm{x}$ & & & & & & & $\mathrm{x}$ & $\mathrm{x}$ & $\mathrm{x}$ & & $\mathrm{x}$ & & & & \\
\hline Polymitarcyidae & & & & & & & & & & & & & & & & & & & \\
\hline Asthenopus Eaton, 1871 & & & & & & & & & & & & $\mathrm{x}$ & $\mathrm{x}$ & & & & & & \\
\hline Campsurus Eaton, 1868 & & & & & & & $\mathrm{x}$ & & & & & $\mathrm{x}$ & & & & $\mathrm{x}$ & & & \\
\hline Oligoneuridae & & & & & & & & & & & & & & & & & & & \\
\hline Lachania Hagen, 1868 & $\mathrm{x}$ & $\mathrm{x}$ & & & $\mathrm{x}$ & & & & & & & & & & & & & & \\
\hline
\end{tabular}




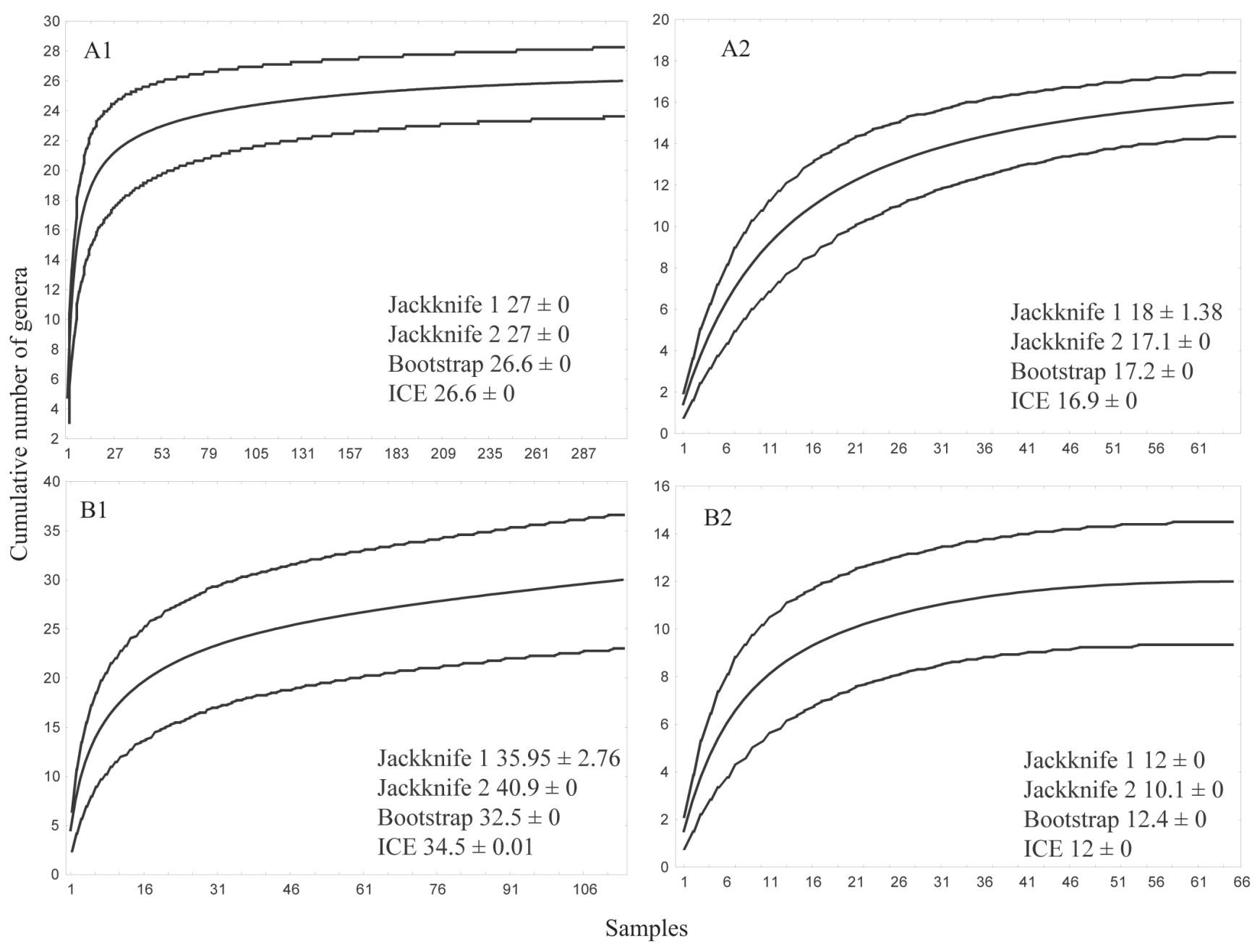

Fig. 2. Genera accumulation curves and richness estimators for nymphs (A1) and alates (A2) of Serra da Mantiqueira and nymphs (B1) and alates (B2) of Serra do Mar, between 2005 and 2008, produced from 500 randomizations. The lines represent the mean curves and the standard deviation of each curve.

sults emphasize that the mountainous regions of São Paulo State harbor a high diversity of aquatic insects, as demonstrated also in studies of Trichoptera (Spies \& Froehlich 2009) and Coleoptera (Segura et al. 2012). The high richness of Ephemeroptera is possibly related to peculiarities of local and regional conditions, such as the heterogeneity of habitats, relief (altitude), vegetation (Tropical Rain Forest and Mixed Forest), and by the state of preservation of the regions concerned. Moreover, the large sampling effort employed contributed to the high richness obtained; as it covered a large area and different environments, and the use of different methods of capture, including sampling of both immature and alate stages.

The results obtained reinforce the need of better conservation programs in these areas, since they are fragmented landscapes and subject to anthropogenic pressure from surrounding areas. In Serra da Mantiqueira, particularly in Parque Estadual de Campos do Jordão, there are records of annual burning and cattle grazing in some areas (Spies \& Froehlich 2009). Grazing affects the stability of the substrate of streams and the biomass of riparian vegetation (Scrimgeour
$\&$ Kendall 2003). The fire causes indirect effects, such as, reduction of habitat and changes in nutrient dynamics, because fire residues are washed by rain into the streams (Minshall 2003). In Pindamonhangaba, the remaining forest fragments are surrounded by vast plantations of Eucalyptus. In Serra do Mar, especially in Picinguaba, there is an irregular occupation in the area of the park.

The efficiency of light attraction methods was already known, due to the nocturnal activity of most genera and attraction to light during copulation. However, other methods are important to complement the faunal inventories, because there are some species with diurnal activity, which are not attracted to light. In this study, alates of the species Hagenulopsis diptera were collected only with entomological nets and Malaise traps, indicating that they have diurnal activity.

The greater diversity recorded in the Serra do Mar is possibly due to collections having been made in larger streams, where Ephemeroptera seem more diversified. In this region, a greater number of third order streams were sampled. Some genera were recorded exclusively in each mountain range, for 

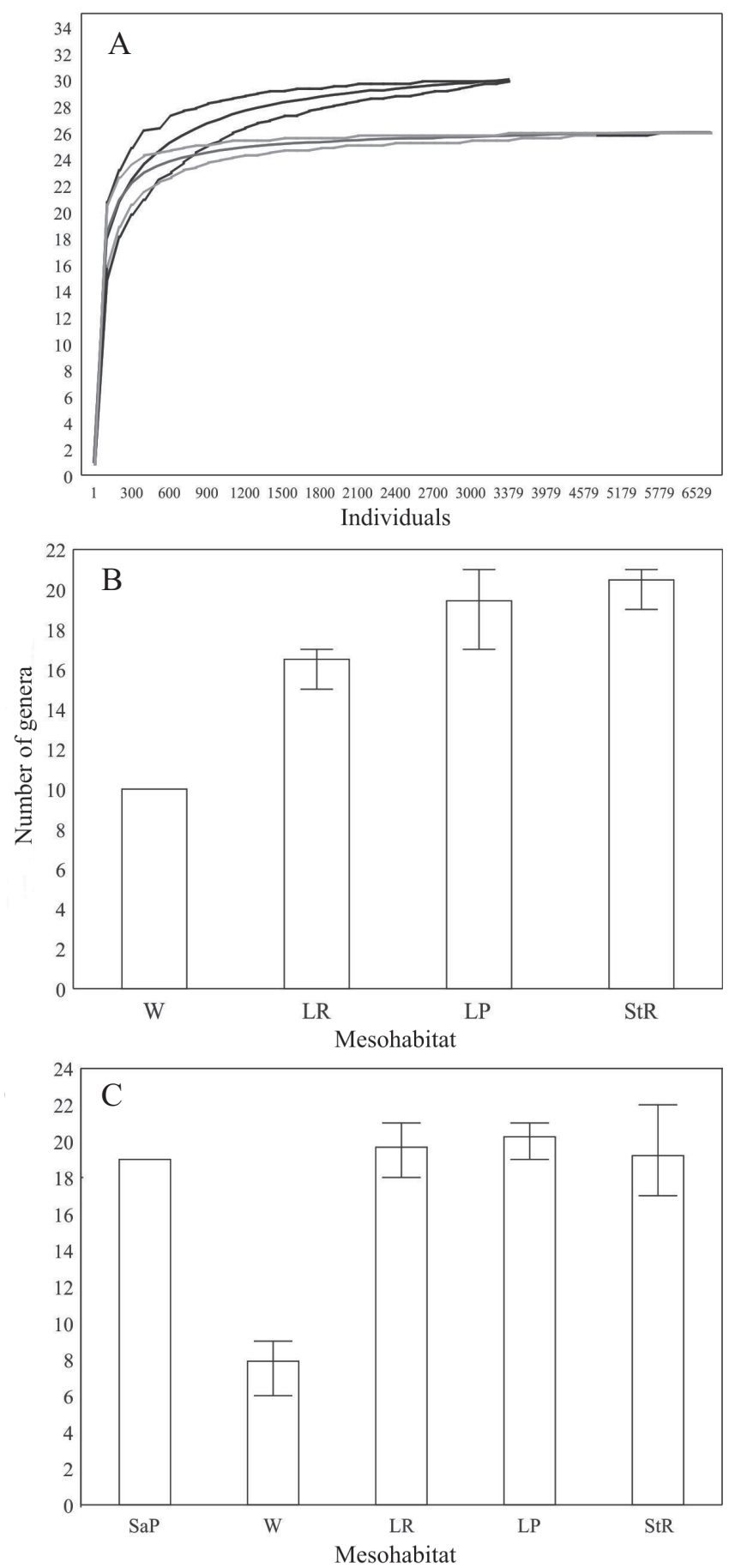

Fig. 3. Rarefaction curves of the Ephemeroptera genera based on immatures collected in Serra do Mar (black line) and Serra da Mantiqueira (gray line) (A), observed richness in different mesohabitats in Serra do Mar (number of individuals $=535)(\mathrm{B})$, and Serra da Mantiqueira (number of individuals $=411$ ) (C), between the years 2005 to 2008 , produced from 1,000 randomizations of the samples order. $\mathrm{W}=$ waterfall; $\mathrm{SaP}=$ sand in pool; $\mathrm{LR}=$ leaf packs in riffles; $\mathrm{LP}=$ leaf packs in pools; $\mathrm{StR}=$ stones in riffles.

example, Callibaetis and Lachania occurred only in Serra da Mantiqueira. The first genus is common and abundant in habitats with low water velocity or lentic environments, habitats sampled only in Serra da Mantiqueira. In Santa Virginia (Serra do Mar), the record of Perissophlebiodes expands the distribution of the genus in São Paulo State, previously recorded only in Parque Estadual Intervales, in the Serra de Paranapiacaba (Polegatto \& Froehlich 2008). The individuals were collected on stones in riffles in low order streams. After the genus description in 1982 very few records of its occurrence have been made, which suggests a restricted distribution and low density of their populations (Polegatto \& Froehlich 2008). This genus is listed as a threatened species in the endangered category (Ministério do Meio Ambiente 2008).

The aquatic habitats are structured by different types of substrates, such as sand, stones, leaves, wood, roots, and macrophytes, all of which exhibit an effect on colonization, persistence and diversity of invertebrates (e.g., Cooper et al. 1997; Scealy et al. 2007). Several studies have shown that diversity of invertebrates increase with the complexity of substrate at finer spatial scales (e.g., Boyero 2003; Mormul et al. 2011). Possible explanations are the increase of food availability (periphyton and detritus) and the increase in refuges (with a reduction in predation risk and from current) (Mazurkiewicz \& Fleituch 2000). Many aquatic insects can occupy more than one type of substrate, but some groups are restricted to specific substrates (Sanseverino et al. 1998). In this study, the hypothesis that greater diversity would be found in a more stable and structurally complex substrate (rocks in riffles) was not supported, but the different taxonomic richness found among mesohabitats especially in Serra do Mar, indicates the preference of some genera to a specific type of substrate or/and environmental condition (water velocity and dissolved $\mathrm{O}_{2}$ ). However, the lack of significant difference in richness among mesohabitats in Serra da Mantiqueira, reinforce the need of more wide and specifically designed studies to test these habitat preferences.

The cumulative curves of genera in both mountain ranges, considering immature and alate stages, indicated the need to increase the sampling effort, since the curves did not stabilize, suggesting that new records can be made in future inventories. This may be explained by the constant presence of rare species in the samples (Santos 2003). Sampling of lentic environments, larger rivers and other habitats should result in records of additional genera in these areas.

The high richness of Ephemeroptera found in the study areas, as well as new species records for the state, emphasizes the importance of the collection of the two life stages, of sampling in many habitats and in the use of complementary methodologies for appropriate faunal inventories. Furthermore, these results reinforce the need for better conservation of parks and encourage the inclusion of new areas into conservation units to maintain high biodiversity in a threatened biome such as the Atlantic Forest.

\section{ACKNOWLEDGMENTS}

We are grateful to K. Righi-Cavallaro, M. Segura, G. Gorni, and V. Orlandini for fieldwork assistance and for assistance in sorting. To E. Domínguez, C. Molineri, and C. 
Nieto for taxonomic assistance. To Fundação de Amparo à Pesquisa do Estado de São Paulo (FAPESP) (proc.n. 05/ 59778-4) for a student fellowship to the first author. This work is part of a thematic project of the BIOTA/FAPESP Program - The Biodiversity Virtual Institute Program (www.biota.org.br) "Levantamento e Biologia de Insecta e Oligochaeta Aquáticos de Sistemas Lóticos do Estado de São Paulo" (proc. no. 2003/10517-9).

\section{REFERENCES}

Barber-James, H. M.; J. L. Gattolliat; M. Sartori; \& M. D. Hubbard. 2008. Global diversity of mayflies (Ephemeroptera, Insecta) in freshwater. Hydrobiologia 595: 339-350.

Baptista, D. F.; D. F. Buss: L. G. Dias; J. L. Nessimian: E. R. Da Silva; A. H. A. De Moraes Neto; S. N. de Carvalho; M. A. De Oliveira \& L. R. Andrade. 2006. Functional feeding groups of Brazilian Ephemeroptera nymphs: ultrastructure of mouthparts. Annales de Limnologie 42: 8796.

Bispo, P. C. \& L. G. Oliveira. 2007. Diversity and structure of Ephemeroptera, Plecoptera and Trichoptera (Insecta) assemblages from riffles in mountain streams of Central Brazil. Revista Brasileira de Zoologia 24: 283-293.

Boyero, L. 2003. The effect of substrate texture on colonization by stream macroinvertebrates. Annales de Limnologie - International Journal of Limnology 39: 211-218.

Brittain, J. E. 1982. Biology of mayflies. Annual Review of Entomology 27:119-147.

Compin, A. \& R. Céréghino. 2003. Sensitivity of aquatic insect species richness to disturbance in the Adour - Garonne stream system (France). Ecological Indicators 3: 135-142.

Colwell, R. K. \& J. A. Coddington. 1994. Estimating terrestrial biodiversity through extrapolation. Philosophical Transactions of the Royal Society of London B 345:101-118.

Colwell, R. K. 2006. EstimateS: Statistical estimation of species richness and shared species from samples. Versions 8. Available from: http:// purl.oclc.org/estimates (accessed 15 January 2012).

Cooper, S. D.; L. Barmuta; O. Sarnelle; K. Kratz \& S. Diehl. 1997. Quantifying spatial heterogeneity in streams. Journal of the North American Benthological Society 16: 174-188.

Cummins, K. W. \& M. J. Klug. 1979. Feeding ecology of stream invertebrates. Annual Review of Ecology and Systematics 10: 147172 .

Crisci-Bispo, V. L.; P. C. Bispo \& C. G. Froehlich. 2007. Ephemeroptera, Plecoptera and Trichoptera assemblages in two Atlantic Rainforest streams, Southeastern Brazil. Revista Brasileira de Zoologia 24: 312 318 .

Dias, L. G.; F. F. Salles; C. N. Francischetti \& P. S. F. Ferreira. 2006. Key to the genera of Ephemerelloidea (Insecta: Ephemeroptera) from Brazil. Biota Neotropica. Available from http://www.biotaneotropica.org.br/ v6n1/pt/abstract?identification-key+bn00806012006 (accessed 15 October 2010).

Domínguez, E. \& H. R. Fernández. 2009. Macroinvertebrados bentónicos sudamericanos: sistemática y biología. Tucumán, Fundación Miguell Lillo, $656 \mathrm{p}$.

Domínguez, E.; C. Molineri; M. Pescador; M. Hubbard \& C. Nieto. 2006. Aquatic Biodiversity in Latin America: Ephemeroptera of South America. Volume 2, Moscow, Pensoft, 646 p.

Domínguez, E.; M. D. Hubbard; M. L. Pescador; C. Molineri \& C. Nieto. 2011. Checklist of South American species of Ephemeroptera. Available from http://www.famu.org/mayfly/sacatdecember2011.pdf (accessed 01 July 2012).

Gonçalves, I. C; Da-Silva, E. R; \& J. L. Nessimian. 2011. Oligoneuria macabaia sp. nov. (Insecta: Ephemeroptera) from Brazil. Revista de Biologia Tropical 59: 1-5.
Gonçalves, I.C.; Da-Silva, E. R.; \& D. M. Takiya. 2012. A remarkable new genus of Atalophlebiinae (Ephemeroptera: Leptophlebiidae) from the Neotropics. Zoologischer Anzeiger 251: 131-138.

Gotelli, N. J. \& R. K. Colwell. 2001. Quantifying biodiversity: procedures and pitfalls in the measurement and comparison of species richness. Ecology Letters 4: 379-391.

Gotelli, N. J. \& G. L. Entsminger. 2001. EcoSim: Null models software for ecology. Version 7.0 Acquired Intelligence Inc. \& Kesey-Bear. Available from http://homepages.together.net gentsmin/ecosim.htm (accessed 15 January 2012).

Hueck, K. 1972. As florestas da América do Sul: ecologia, composição e importância econômica. São Paulo: Ed. Polígono, xxiii, 466 p.

Mariano, R. \& C. Polegatto. 2011. Checklist of Ephemeroptera from São Paulo State, Brazil. Biota Neotropica 11, suppl. 1: 593-599.

Mazurkiewicz, G. \& T. Fleituch. 2000. Patterns of benthic diversity in a mountain river. Verhandlungen der Internationale Vereinigung für Limnologie 27: 2529-2534.

Ministério do Meio Ambiente. 2008. A. B. M. Machado; G. M. Drummond \& A. P. Paglia (Eds). Livro Vermelho da Fauna Brasileira Ameaçada de Extinção. Brasília, MMA, Secretaria de Biodiversidade e Florestas, Departamento de Conservação da Biodiversidade, Volume 1, 511 p.

Minshall, G. W. 2003. Responses of stream benthic macroinvertebrates to fire. Forest Ecology and Management 178: 155-161.

Mormul, R. P.; S. M. Thomaz; A. M. Takeda \& R. D. Behrend. 2011. Structural complexity and distance from source habitat determine invertebrate abundance and diversity. Biotropica 43: 738-745.

Moulton, T. P.; M. L. de Souza; R. M. L. Silveira; \& F. A. M. Krsuloviæ. 2004. Effects of ephemeropterans and shrimps on periphyton and sediments in a coastal stream (Atlantic forest, Rio de Janeiro, Brazil). Journal of the North American Benthological Society 23: 868-881.

Polegatto, C. M. \& C. G. Froehlich. 2003. Feeding strategies in Atalophlebiinae (Ephemeroptera: Leptophlebiidae), with considerations on scraping and filtering, p. 55-61. In: E. Gaino (Ed.). Research update on Ephemeroptera and Plecoptera. Perugia, University of Perugia, $488 \mathrm{p}$.

Righi-Cavallaro K. O; M. R. Spies \& A. E. Siegloch. 2010. Ephemeroptera, Plecoptera and Trichoptera assemblages in Miranda River Basin, Mato Grosso do Sul State, Brazil. Biota Neotropica 10: 253-260.

Rosenberg, D. M. \& V. H. Resh. 1993. Freshwater monitoring and benthic macroinvertebrates. New York, Chapman \& Hall, 504 p.

Salles, F. F.; E. R. Da-Silva; J. E. Serrão \& C. N. Francischetti. 2004. Baetidae (Ephemeroptera) na Região Sudeste do Brasil: novos registros e chave para os gêneros no estágio ninfal. Neotropical Entomology 33: 569576.

Salles, F. F.; R; Boldrini; J. C. M. Nascimento; E. A Raimundi \& Y. F Shimano. 2011. Ephemeroptera do Brasil. Available from https:// sites.google.com/site/ephemeropterabr (accessed 30 June 2012).

Sanseverino, A. M.; J. L. Nessimian \& A. L. H. Oliveira. 1998. A fauna de Chironomidae (Diptera) em diferentes biótopos aquáticos na Serra do Subaio (Teresópolis, RJ), p. 253-263. In: J. L. Nessimian \& A.L. Carvalho (eds). Ecologia de Insetos Aquáticos. Vol. V, Rio de Janeiro, Serie Oecologia Brasiliensis PPGE-UFRJ.

Santos, A. J. 2003. Estimativas de riqueza em espécies, p. 19-41. In: L. Cullen Jr., C. Valladares-Padua \& R. Rudram (eds.). Métodos de Estudos em Biologia da Conservação e Manejo da Vida Silvestre. Curitiba, Editora da UFPR, 41 p.

Scealy, J. A.; S. J. Mika \& A. J. Boulton. 2007. Aquatic macroinvertebrate communities on wood in an Australian lowland river: Experimental assessment of the interactions of habitat, substrate complexity and retained organic matter. Marine \& Freshwater Research 58: 153165.

Scrimgeour, G. J. \& S. Kendall. 2003. Effects of livestock grazing on benthic invertebrates from a native grassland ecosystem. Freshwater Biology 48: $347-362$.

Segura, M. O.; A. A. Fonseca-Gessner; M. R. Spies \& A. E. Siegloch. 2012. Water beetles in mountainous regions in Southeastern Brazil. Brazilian Journal of Biology 72: 311-321. 
Seibert, P. 1975. Plano de manejo do Parque Estadual de Campos do Jordão. Boletim Técnico do Instituto Florestal 19: 1-153.

Siegloch, A. E.; C. G. Froehlich \& C. B. Kotzian. 2008. Composition and diversity of Ephemeroptera Haeckel 1896 (Insecta) nymph communities in the middle section of the Jacuí River and some tributaries,
State of Rio Grande do Sul, Brazil. Iheringia, Série Zoologia 98: 425-432.

Spies, M. R. \& C. G. Froehlich. 2009. Inventory of caddisflies (Trichoptera: Insecta) of the Campos do Jordão State Park, São Paulo State, Brazil. Biota Neotropica 9: 211-218

Received 31/1/2012; accepted 13/11/2012

Editor: Daniela Maeda Takiya 